\title{
KARAKTER MORFOLOGI DAN FISIOLOGI PERKECAMBAHAN UMBI BAWANG PUTIH (Allium sativum L.) PADA PENYIMPANAN SUHU RENDAH
}

\author{
Selis Meriem*, Devi Armita, Rahmat Fajrin Alir, Masriany \\ Jurusan Biologi \\ Fakultas Sains dan Teknologi Universitas Islam Negeri Alauddin Makassar \\ Jl. Sultan Alauddin No. 63, Kabupaten Gowa, Sulawesi Selatan. 92113 \\ E-mail: selis.meriem@uin-alauddin.ac.id
}

\begin{abstract}
Abstrak: Produktivitas bawang putih yang terbatas di Indonesia membuat komoditas impor semakin meningkat. Perkecambahan bawang putih sangat bergantung pada faktor abiotik yang terkontrol dan tepat termasuk paparan suhu dan kelembaban, karena itu bawang putih ini dapat mengalami fase dorman. Namun, penelitian yang berfokus pada perkecambahan bawang putih masih jarang dilakukan. Penelitian ini dilakukan untuk mengukur karakteristik morfologi dan fisiologis siung bawang putih (Allium sativum L.) yang diberi perlakuan suhu yang bervariasi. Perlakuan dilakukan secara eksperimen faktorial dengan satu faktor suhu kamar (K) sebagai kontrol, suhu rendah (dingin) selama 3 hari (R3) dan 5 hari (R5). Suhu dingin dirancang pada $7^{\circ} \mathrm{C}$, sedangkan kontrol pada suhu $29^{\circ} \mathrm{C}$. Perlakuan awal perkecambahan bawang putih tidak berpengaruh nyata terhadap parameter fisiologis. Namun, perlakuan R5 menunjukkan nilai rata-rata yang jauh lebih tinggi yaitu 18,75\% dan persentase kecepatan perkecambahan 16,32\% lebih tinggi dibandingkan dengan perlakuan lainnya. Selanjutnya, penyimpanan pada suhu $7^{\circ} \mathrm{C}$ selama 3 hari menunjukkan laju pertumbuhan 76,44\% dan $45,75 \%$ lebih tinggi, serta indeks vigor $76,73 \%$ dan $45,76 \%$ lebih tinggi dibandingkan perlakuan R3 dan kontrol. Perlakuan R5 secara nyata meningkatkan tinggi tanaman, panjang akar dan jumlah daun yang masing-masing $66,43 \%, 54,45 \%$, dan $50 \%$ lebih tinggi dibandingkan dengan R3 dan 84,26\%, 61,79\%, dan 50\% lebih tinggi dari pada tanaman kontrol. Hasil yang diperoleh menunjukkan bahwa perawatan pra-perkecambahan dalam penyimpanan dingin dapat menginduksi pertumbuhan dan proses perkecambahan yang lebih baik. Untuk meningkatkan varietas bawang putih lokal di Indonesia perlu kajian lebih lanjut khususnya lama penyimpanan dingin yang tepat untuk mengatur dormansi yang mungkin terjadi pada budidaya bawang putih di luar musim tanam yang sesuai.
\end{abstract}

Kata Kunci: Allium sativum L., perkecambahan, vernalisasi

\section{PENDAHULUAN}

B awang putih (Allium sativum L.) telah dikenal manfaatnya dalam berbagai aspek, tidak hanya sebagai bumbu utama masakan tapi juga berfungsi sebagai antibakteri, antiparasit, antivirus, anti kanker, anti inflamasi dan imunomudulator secara farmakologi (Clement et al., 2010; Saif et al., 2020; Kaur et al., 2021) serta berpotensi sebagai bahan alam bioinsektisida (Meriga et al., 2012; Shamsi et al., 2018). 
Tingginya permintaan bawang putih tidak diikuti dengan peningkatan sektor produksi sehingga memunculkan kecenderungan impor yang lebih tinggi. Hal ini disebabkan oleh penurunan luas panen di Indonesia sejak tahun 1999 sebesar 29.07\% dan rendahnya produksi selama periode 2008-2017 dibandingkan tahun sebelumnya (Kementerian Pertanian, 2020). Walaupun terjadi peningkatan luas panen dan produksi pada tahun 2018, namun kondisi ini masih belum memenuhi kebutuhan komoditas bawang putih di Indonesia. Daya produksi yang rendah disebabkan oleh kurangnya manajemen penanganan hama dan perkembangan penyakit busuk akar, kurangnya inovasi teknologi, serta tingginya daya saing bawang putih impor dengan harga jual yang lebih rendah dibandingkan varietas lokal. Oleh sebab itu, fenomena ini merupakan masalah komoditas yang serius dan perlu untuk segera ditindaklanjuti melalui studi berkelanjutan dengan harapan dapat meningkatkan produksi bawang putih lokal Indonesia dan mengurangi impor komoditas hortikultura.

Perbanyakan bawang putih hanya dapat dilakukan secara vegetatif karena sifatnya yang steril. Perkecambahan, pertumbuhan dan pembungaan umbi ini sangat dipengaruhi oleh faktor abiotik yaitu suhu dan fotoperiode serta jenis benih dan penyimpanan (Kamenetsky \& Dagan, 2017). Produktivitas bawang putih juga sangat ditentukan oleh faktor lingkungan dan iklim mikro tanaman (Muhammad \& Soelistyono, 2020). Secara fisiologi, benih umbi yang baru dipanen berada pada fase dorman sehingga induksi perkecambahan sangat bergantung terhadap suhu dan kelembaban, termasuk fitohormon dan nutrien (Kamenetsky \& Rabinowitch, 2006; Xue et al., 2021). Penelitian tentang priming benih sebelum penanaman telah banyak dilakukan pada berbagai jenis tanaman (Kumar et al., 2012; Farooq et al., 2019; Nafees et al., 2019), namun studi pra perkecambahan umbi bawang putih masih belum banyak dieksplor saat ini.

Fluktuasi iklim yang tidak menentu juga sangat menganggu respon umbi dalam inisiasi perkecambahan dan induksi fase pembungaan. Penelitian ini bertujuan untuk menganalisis karakter fisiologi perkecambahan dan morfologi pada umbi bawang putih (Allium sativum L.) setelah dipaparkan pada suhu rendah dan suhu ruang. Hasil ini merupakan landasan penelitian dalam mengembangkan studi jangka panjang yang bertujuan menghasilkan teknologi budidaya bawang putih yang akurat. Aplikasi penelitian ini memungkinkan penanaman umbi melalui kontrol iklim mikro sehingga budidaya dapat dilakukan selain pada masa tanam.

\section{METODE PENELITIAN}

Penelitian ini dilaksanakan di Laboratorium Botani Jurusan Biologi, Fakultas Sains dan Teknologi, UIN Alauddin Makassar selama bulan November 2020. Penelitian ini menggunakan Rancangan Acak Lengkap (RAL) satu faktor yaitu dengan pemberian suhu. Perlakuan terdiri dari tiga taraf yaitu suhu ruang $\left(29^{\circ} \mathrm{C}\right)$, suhu rendah $\left(7^{\circ} \mathrm{C}\right)$ selama 3 hari dan suhu rendah $\left(7^{\circ} \mathrm{C}\right)$ selama 5 hari. Masing-masing perlakuan terdiri diulang sebanyak tiga kali sehingga terdapat 21 satuan percobaan. Setiap ulangan terdiri dari 20 buah umbi bawang putih (Allium sativum L.)

\section{Penanaman umbi dan pemberian perlakuan}

Umbi bawang putih yang berumur tiga bulan sejak panen dibersihkan dan dirumih. Benih yang memiliki bobot $3 \mathrm{~g}$ dan bebas penyakit dipilih sebagai sampel. Perlakuan suhu rendah dilakukan dengan penyimpanan umbi pada lemari pendingin $\left(7^{\circ} \mathrm{C}\right)$ selama 3 hari dan 5 hari. Selama penyimpanan suhu rendah, umbi disimpan dalam plastik kedap udara steril. Setelah pemberian perlakuan, bagian cakram umbi ditanam pada media 
tumbuh dengan perbandingan tanah: kompos (1:1) dengan jarak tanam antar siung yaitu $10 \mathrm{~cm}$. Penanaman, penyiraman dan penyiangan dilakukan selama 12 hari pengamatan.

\section{Parameter morfologi}

Pengukuran tinggi tanaman, panjang akar dan jumlah daun dilakukan setiap hari pengamatan. Tinggi tanaman diukur mulai dari pangkal batang semu sampai dengan bagian daun terpanjang. Panjang akar diukur dari pangkal akar sampai dengan ujung akar terpanjang. Pengukuran dilakukan menggunakan pita ukur $(0.01 \mathrm{~cm})$.

\section{Parameter mutu fisiologis}

Pengamatan daya berkecambah (DB), kecepatan tumbuh (KCT), dan indeks vigor (IV) diukur setiap hari, sedangkan panjang akar diukur pada 12 HST (Hari Setelah Tanam).

Daya berkecambah

$$
=\frac{\Sigma \text { benih berkecambah }}{\Sigma \text { benih yang ditumbuhkan }} \times 100 \%
$$

$$
\begin{array}{ll}
\text { Waktu berkecambah (hari) } & =\frac{N 1 t 1+N 2 t 2+N 3 t 3+\cdots+N 12 t 12}{\Sigma \text { benih yang berkecambah }} \\
\text { Kecepatan tumbuh (KCT) } & =\frac{\% N 1}{\text { etmal } 1}+\frac{\% N 2}{\text { etmal } 2}+\cdots+\frac{\% N 12}{\text { etmal } 12} \\
\text { Indeks Vigor (IV) } & =\frac{N 1}{t 1}+\frac{N 2}{t 2}+\frac{N 3}{t 3}+\cdots+\frac{N 12}{t 12}
\end{array}
$$

Keterangan:

$\begin{array}{ll}\mathrm{N} & =\text { Jumlah benih yang berkecambah } \\ \% \mathrm{~N} & =\text { Persentase jumlah benih yang berkecambah terhadap total benih } \\ 1 \mathrm{etmal} & =24 \text { jam } \\ \mathrm{t} & =\text { Waktu (hari) benih berkecambah }\end{array}$

Data parameter morfologi dan fisiologi umbi dianalisis dengan uji ANOVA oneway. Jika terdapat pengaruh yang signifikan maka data diuji lanjut dengan Tukey HSD. Proses analisis menggunakan software statistik IBM versi 25.0 pada $p=0.05$.

\section{HASIL DAN PEMBAHASAN}

1. Pengaruh Lama Suhu Rendah terhadap Karakter Fisiologi Perkecambahan

Penyimpanan pada suhu rendah tidak berpengaruh nyata terhadap daya berkecambah, waktu berkecambah, kecepatan tumbuh dan indeks vigor (Gambar 1). Namun nilai mean menunjukkan parameter fisiologi yang lebih tinggi pada penyimpanan suhu rendah 5 hari (R5) dibandingkan suhu rendah 3 hari (R3) dan kontrol. Secara ratarata, perlakuan R5 menunjukkan $18.75 \%$ dan $16.32 \%$ lebih tinggi untuk parameter daya berkecambah, $76.44 \%$ dan $45.75 \%$ lebih tinggi untuk parameter kecepatan tumbuh, $76.73 \%$ dan $45.76 \%$ lebih tinggi untuk parameter indeks vigor dibandingkan umbi perlakuan R3 dan K secara berurutan. Sedangkan umbi pada perlakuan R5 menunjukkan waktu berkecambah yang secara rata-rata $15.25 \%$ dan $8.25 \%$ lebih cepat dibandingkan R3 dan kontrol. Dengan demikian, penyimpanan umbi bawang putih pada suhu rendah $\left(7^{\circ} \mathrm{C}\right)$ selama 5 hari telah dibuktikan mampu meningkatkan daya berkecambah yang lebih cepat dengan kecepatan tumbuh dan indeks vigor yang lebih baik. 

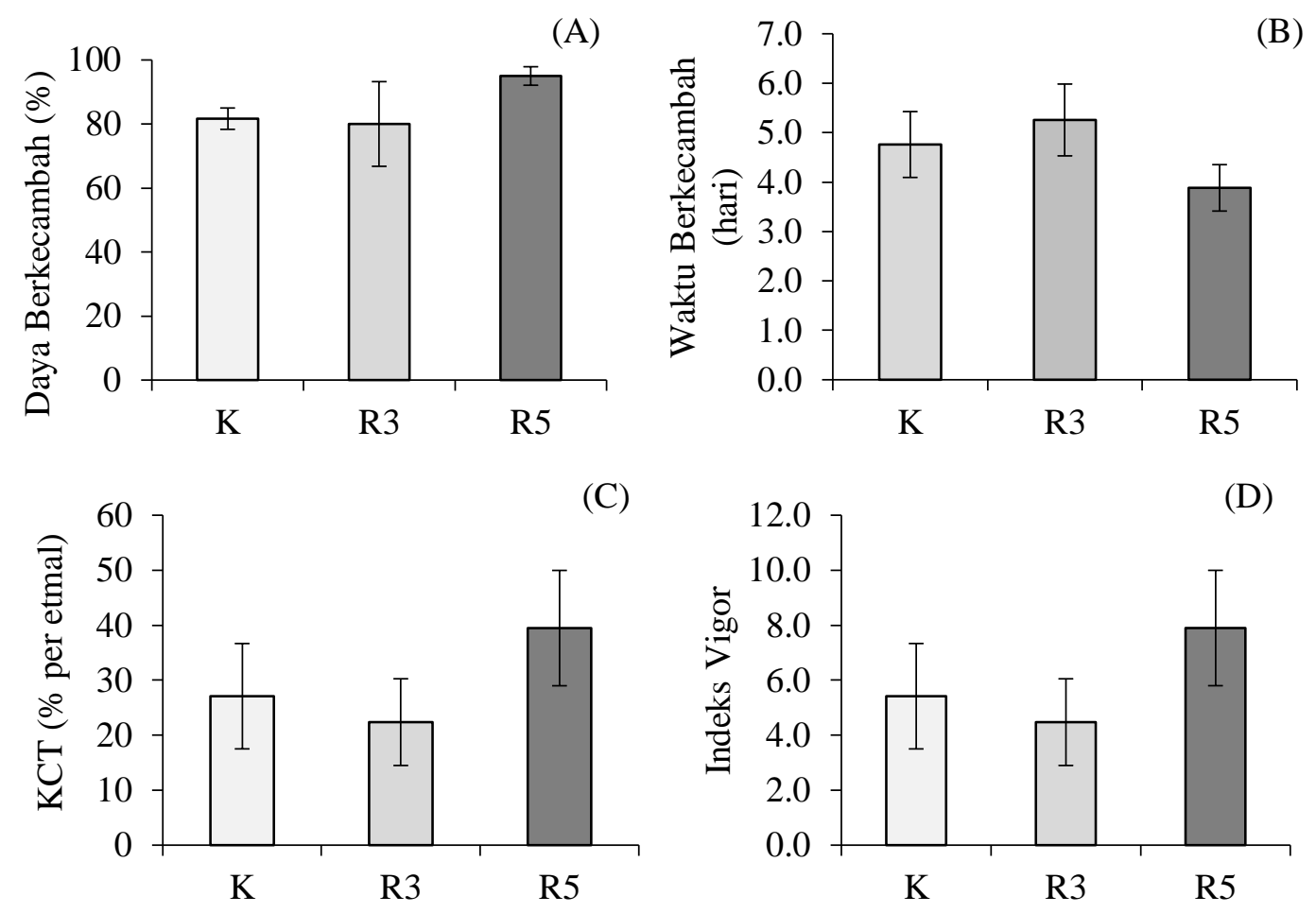

Gambar 1. Pengaruh lama suhu rendah terhadap (A) daya berkecambah (\%), (B) Waktu berkecambah (hari, (C) Kecepatan tumbuh (KCT) dan (D) Indeks vigor umbi bawang putih (Allium sativum L.) pada 12

HST. Huruf yang berbeda menunjukkan beda nyata dengan $p<0.01$ (Uji Tukey HSD). $\mathrm{K}=\mathrm{Kontrol}$ (Suhu ruang $29^{\circ} \mathrm{C}$ ), $\mathrm{R} 3=\mathrm{Suhu}$ dingin $7^{\circ} \mathrm{C} 3$ hari, $\mathrm{R} 5=$ Suhu dingin $7^{\circ} \mathrm{C} 5$ hari.

Masa dormansi umbi bawang putih yang lebih singkat dan daya kecambah yang tinggi dikontrol oleh penyimpanan benih pada suhu rendah (Woldeyes et al., 2017; Siahaan, 2020). Studi lain juga menunjukkan hasil yang sama bahwa suhu $7^{\circ} \mathrm{C}$ selama 65 hari mempercepat waktu berkecambah dengan persentase perkecambahan yang lebih tinggi dibandingkan tanaman kontrol (Lucidos et al., 2014). Persentase daya berkecambah bawang putih cv. Lumbu Kuning yang tinggi juga didapatkan selama penyimpanan benih pada suhu rendah $5^{\circ} \mathrm{C}$ (Nurmalia et al., 2019). Perkecambahan fisiologis yang lebih baik pada penyimpanan suhu rendah mungkin disebabkan oleh induksi dan aktivasi hormon endogen yang berperan dalam memecah dormansi dan meningkatan orientasi pembelahan meristem tajuk dan akar dalam pertumbuhan. Paparan suhu rendah meningkatan ekspresi gen biosintesis hormon giberelin (GA) dan menghambat gen deaktivasi GA sehingga dapat memicu sintesis enzim $\alpha$-amilase yang berfungsi dalam hidrolisis pati menjadi gula terlarut (Li \& Yang, 2020). Konsentrasi GA endogen yang rendah menurunkan reaksi hidrolisis pati dan akumulasi gula terlarut yang ditransportasi menuju endosperma sehingga berpotensi menghambat perkecambahan benih (Wang et al., 2018). Beberapa studi telah membuktikan bahwa persentase daya kecambah yang rendah sangat kuat hubungannya dengan reduksi aktivitas enzim amilase dan konsentrasi gula terlarut yang rendah (Kaneko et al., 2002). Gula ini akan ditranslokasi dari endosperma ke embrio melalui transporter sukrosa yang diregulasi oleh gen spesifik pada lapisan aleuron (Chung et al., 2013). Gula terlarut berfungsi sebagai energi utama bagi embrio untuk berkecambah dan berkembang. 
Tingginya daya kecambah pada perlakuan kontrol dapat disebabkan oleh umur simpan umbi sejak panen yang lebih lama yaitu lebih dari 12 minggu sehingga benih mulai memasuki fase pecah dormansi pada durasi ini. Oleh sebab itu, peneliti menyarankan studi selanjutnya untuk menggunakan benih segar sejak panen untuk melihat pengaruh variasi suhu rendah dan interaksinya dengan lama penyimpanan yang signifikan.

\section{Pengaruh Lama Suhu Rendah terhadap Karakter Morfologi}

Penyimpanan umbi bawang putih (Allium sativum L.) pada suhu rendah selama 5 hari (R5) nyata meningkatkan tinggi tanaman pada hari ke-7 sampai akhir pengamatan (Gambar 2) serta panjang akar dan jumlah daun lebih tinggi secara signifikan pada 12 HST (Gambar 3) dibandingkan dengan penyimpanan suhu rendah selama 3 hari (R3) dan kontrol (K). Grafik pertumbuhan (Gambar 3) menunjukkan tren peningkatan tinggi tanaman sebanyak dua kali lipat lebih tinggi pada penyimpanan R5. Nilai tertinggi ditunjukkan oleh penyimpanan R5 pada 12 HST, dengan tinggi tajuk $66.43 \%$ dan $84.26 \%$ lebih tinggi dibandingkan dengan R3 dan K secara berurutan. Lebih lanjut panjang akar R5 juga $54.45 \%$ dan $61.79 \%$ lebih panjang secara signifikan dibandingkan perlakuan R3 dan K secara berurutan. Selain itu, jumlah daun R5 pada 12 HST juga nyata 50\% lebih banyak dibandingkan perlakuan lainnya.

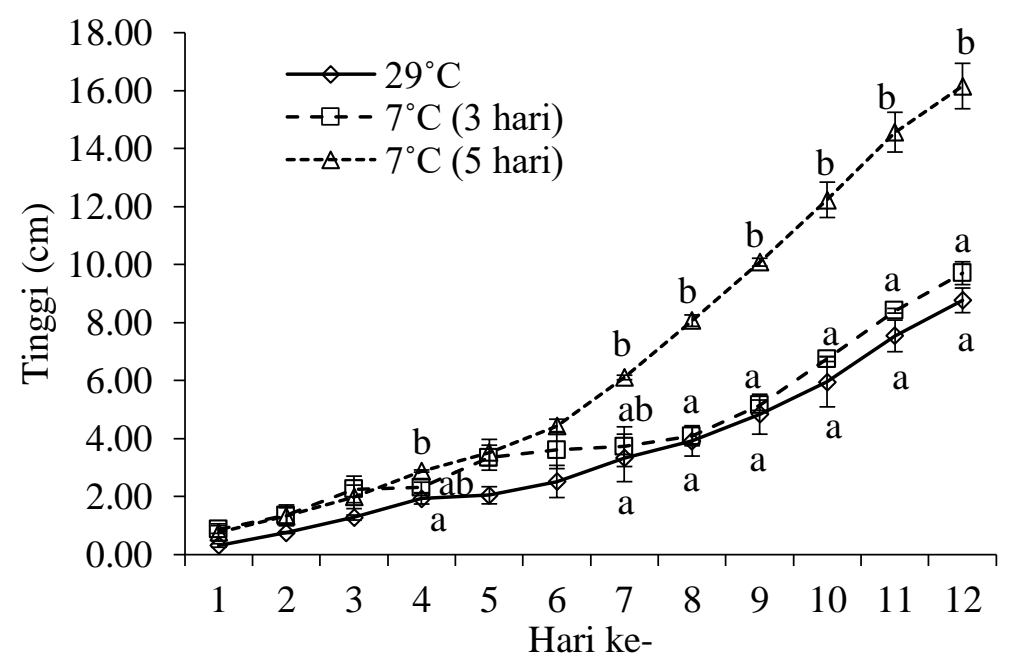

Gambar 2. Pengaruh lama suhu rendah terhadap tinggi kecambah umbi bawang putih (Allium sativum L.)

Penyimpanan umbi pada suhu rendah dengan durasi terlama juga telah dilaporkan oleh hasil studi lainnya. Wu et al., (2015) melaporkan bahwa suhu rendah $5^{\circ} \mathrm{C}$ selama periode terlama 60 hari mampu memicu pemanjangan batang, panjang dan diameter daun, laju perkecambahan, dan panen yang lebih cepat. Peningkatan tinggi batang semu sebanyak $40.51 \%$ setelah penyimpanan suhu rendah juga meningkatkan bobot kering sebesar $79.41 \%$ (Bizuayehu et al., 2018). Pertumbuhan tajuk yang optimum berelasi positif dengan proses pembentukan umbi yang lebih baik. Atif et al., (2020) melaporkan bahwa pertumbuhan tajuk baik dari parameter tinggi dan batang semu mendukung pertumbuhan umbi dengan karakter morfologi yang lebih baik pada suhu yang lebih rendah. Pada saat pengisian umbi, nutrisi dan simpanan (karbon dan nitrogen) ditranslokasi dari bagian vegetatif. Dengan demikian, pertumbuhan vegetatif sangat menentukan kualitas umbi. 

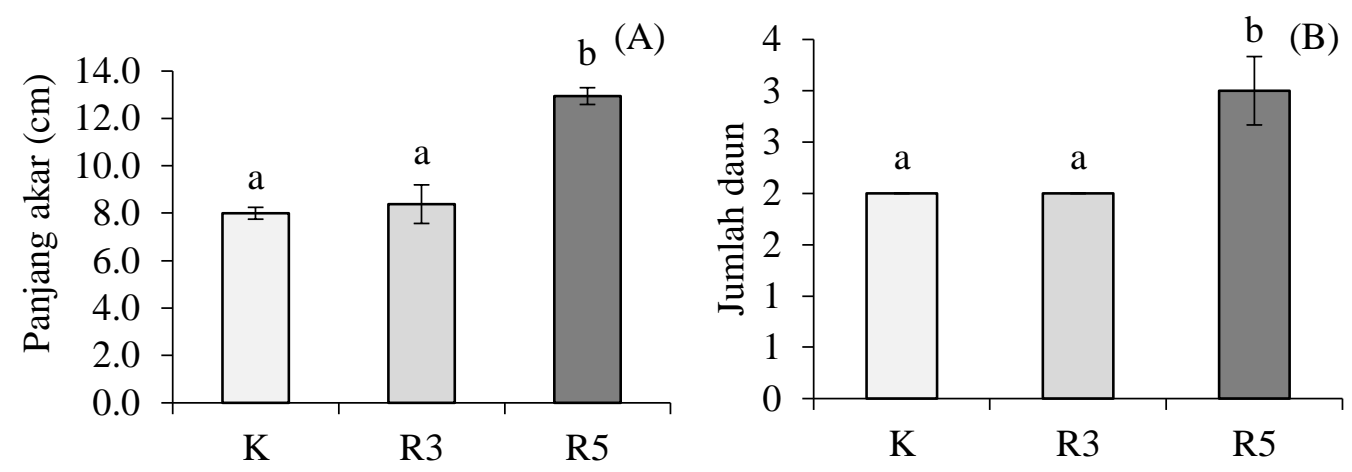

Gambar 3. Pengaruh lama suhu rendah terhadap (A) panjang akar dan (B) jumlah daun umbi bawang putih (Allium sativum L.) pada $12 \mathrm{HST}$. Angka yang berbeda menunjukkan beda nyata dengan $p<0.01$ (Uji Tukey HSD). $\mathrm{K}=$ Kontrol (Suhu ruang $29^{\circ} \mathrm{C}$ ), R3 = Suhu dingin $7^{\circ} \mathrm{C} 3$ hari, $\mathrm{R} 5=$ Suhu dingin $7^{\circ} \mathrm{C} 5$ hari.

\section{KESIMPULAN}

Perlakuan suhu dingin tidak berpengaruh secara signifikan terhadap karakter perkecambahan fisiologis. Walaupun demikian, penyimpanan umbi pada suhu dingin selama 5 hari memiliki rata-rata persentase daya berkecambah, kecepatan tumbuh, dan indeks vigor yang lebih baik dengan masa muncul kecambah lebih cepat dibandingkan suhu dingin selama 3 hari dan kontrol. Pemberian perlakuan suhu dingin $\left(7^{\circ} \mathrm{C}\right)$ sebelum penanaman pada umbi bawang putih (Allium sativum L.) selama 5 hari mampu meningkatkan karakter morfologi berupa tinggi tanaman, panjang akar dan jumlah daun yang lebih baik.

\section{DAFTAR PUSTAKA}

Atif, M. J., Amin, B., Ghani, M. I., Ali, M., Zhang, S., \& Cheng, Z. (2020). Effect of photoperiod and temperature on garlic (Allium sativum L.) bulbing and selected endogenous chemical factors. Environmental and Experimental Botany, 180, 104250. doi: doi.org/10.1016/j.envexpbot.2020.104250.

Bizuayehu, D., Kebede, W., Wassu, W., Bekele, A., \& Getachew, T. (2018). Duration of low temperature storage, clove topping and gibberellic acid on garlic sprouting and seedling vigor. African Journal of Food, Agriculture, Nutrition and Development, 18(2), 13420-13437. doi: doi.org/10.18697/ajfand.82.17065.

Chung, P., Hsiao, H.-H., Chen, H.-J., Chang, C.-W., \& Wang, S.-J. (2013). Influence of temperature on the expression of the rice sucrose transporter 4 gene, OsSUT4, in germinating embryos and maturing pollen. Acta Physiologiae Plantarum, 36, 217-229. doi: doi.org/10.1007/s11738-013-1403-x.

Farooq, M., Hussain, M., Imran, M., Ahmad, I., Atif, M., \& Alghamdi, S. S. (2019). Improving the productivity and profitability of late sown chickpea by seed priming. International Journal of Plant Production, 13, 129-139. doi: doi.org/10.1007/s42106-019-00041-z.

Kamenetsky, R, \& Dagan, B. (2017). Physiology of domesticated Alliums: onions, garlic, leek, and minorcrops. Encyclopedia of Applied Plant Sciences, 3, 255-261. doi: doi.org/10.1016/B978-0-12394807-6.00064-2.

Kamenetsky, Rina, \& Rabinowitch, H.D. (2006). The Genus Allium: A Developmental and Horticultural Analysis. In J. Janick (Ed.). Horticultural Reviews, 32, 329-378.

Kaneko, M., Itoh, H., Ueguchi-tanaka, M., Ashikari, M., \& Matsuoka, M. (2002). The $\alpha$-amylase induction in endosperm during rice seed germination is caused by gibberellin synthesized in epithelium. Plant Physiology, 128(4), 1264-1270. doi: doi.org/10.1104/pp.010785.1264.

Kaur, R., Tiwari, A., Manish, M., Maurya, I. K., Bhatnagar, R., \& Singh, S. (2021). Common Garlic (Allium sativum L.) Has Potent Anti-Bacillus Anthracis Activity. Journal of Ethnopharmacology, 264, 113230. doi: doi.org/10.1016/j.jep.2020.113230.

Kementerian Pertanian. (2020). Outlook Bawang Putih - Komoditas Pertanian Subsektor Hortikultura (A. 
A. Susanti \& M. A. Supriyatna (eds.). Jakarta: Pusat Data dan Sistem Informasi Pertanian.

Kumar, B., Verma, S. K., Ram, G., \& Singh, H. P. (2012). Temperature relations for seed germination potential and seedling vigor in Palmarosa (Cymbopogon martinii). Journal of Crop Improvement, 26(6), 791-801. doi: doi.org/10.1080/15427528.2012.689799.

Li, Q., \& Yang, A. (2020). Comparative Studies on Seed Germination of Two Rice Genotypes with Different Tolerances to Low Temperature. Environmental and Experimental Botany, 179, 104216. doi: doi.org/10.1016/j.envexpbot.2020.104216.

Lucidos, J.G., Younis, A., Hwang, Y., \& Lim, K. (2014). Determination of Optimum Conditions For Breaking Bulb Dormancy in Relation to Growth and Flowering in Lilium hansonii. Orticulture, Environment and Biotechnology, 55(4), 257-262. doi: doi.org/10.1007/s13580-014-0143-1.

Meriga, B., Mopuri, R., \& Muralikrishna, T. (2012). Insecticidal, Antimicrobial and Antioxidant Activities of Bulb Extracts of Allium sativum. Asian Pacific Journal of Tropical Medicine, 5(5), 391-395. doi: doi.org/10.1016/S1995-7645(12)60065-0.

Muhammad, C.F., \& Soelistyono, R. (2020). Kajian Dampak Perubahan Iklim terhadap Produktivitas Bawang Putih (Allium sativum L.) di Kabupaten Malang. Jurnal Produksi Tanaman, 8(9), 886-891.

Nafees, K., Kumar, M., \& Bose, B. (2019). Effect of Different Temperatures on Germination and Seedling Growth of Primed Seeds of Tomato. Russian Journal of Plant Physiology, 66(5), 778-784. doi: doi.org/10.1134/S1021443719050169.

Nurmalia, N., Purwanto, Y. A., Sobir, S., Sulassih, S., \& Naibaho, N. (2019). Effect of Low Temperature and Period of Storage on The Quality of Garlic Seeds (Allium sativum L). IOP Conf. Series: Materials Science and Engineering 557, 1-6. doi: doi.org/10.1088/1757-899X/557/1/012088.

Saif, S., Hanif, M. A., Rehman, R., \& Riaz, M. (2020). Garlic. Medicinal Plants of South Asia. 301-315. doi: doi.org/10.1016/B978-0-08-102659-5.00023-9.

Shamsi, T. N., Parveen, R., Ahmad, A., Samal, R. R., Kumar, S., \& Fatima, S. (2018). Inhibition of gut proteases and development of dengue vector, Aedes aegypti by Allium sativum protease inhibitor. Acta Ecologica Sinica, 38(5), 325-328. doi: doi.org/10.1016/j.chnaes.2018.01.002.

Siahaan, S.P. (2020). Pengaruh Pre-Treatment Dalam Proses Curing dan Suhu Penyimpanan terhadap Mutu dan Masa Dormansi Benih Bawang Putih. Jurnal Keteknikan Pertanian, 8(1), 29-38. doi: doi.org/10.19028/jtep.08.1.29-38.

Wang, Y., Cui, Y., Hu, G., Wang, X., Chen, H., Shi, Q., Xiang, J., Zhang, Y., Zhu, D., \& Zhang, Y. (2018). Reduced Bioactive Gibberellin Content in Rice Seeds Under Low Temperature Leads to Decreased Sugar Consumaption and Low Seed Germination Rates. Plant Physiology and Biochemistry, 133, 1-10. doi: Doi.org/10.1016/j.plaphy.2018.10.020.

Woldeyes, F., Kebede, W., \& Tabor, G. (2017). Emergence of Garlic (Allium sativum L.) as Influenced by Low Storage Temperature and Gibberellic Acid Treatments. Journal of Agriculture and Ecology Research International, 10(2), 1-7. doi: doi.org/10.9734/JAERI/2017/29843.

Wu, C., Wang, M., Dong, Y., Cheng, Z., \& Meng, H. (2015). Growth, bolting and yield of garlic (Allium sativum L.) in response to clove chilling treatment. Scientia Horticulturae, 194, 43-52. doi: doi.org/10.1016/j.scienta.2015.07.018.

Xue, X., Du, S., Jiao, F., Xi, M., Wang, A., Xu, H., Jiao, Q., Zhang, X., Jiang, H., Chen, J., \& Wang, M. (2021). The Regulatory Network Behind Maize Seed Germination: Effects of Temperature, Water, Phytohormones, and Nutrients. The Crop Journal, In Press. doi: Doi.org/10.1016/j.cj.2020.11.005. 